\title{
Bachelor's Degree
}

National Cancer Institute

\section{Source}

National Cancer Institute. Bachelor's Degree. NCI Thesaurus. Code C39327.

Bachelor's degree is an award (baccalaureate or equivalent degree, as determined by the Secretary of the U.S. Department of Education) conferred by a college, university, or other postsecondary education institution as official recognition for the successful completion of a program of studies, that normally requires at least four years of full-time equivalent college-level work. This includes bachelor's deg rees conferred in a five-year cooperative program. 